\title{
Overview of Risk Factors and Prevention of Capsular Contracture Following Implant-Based Breast Reconstruction and Cosmetic Surgery: A Systematic Review
}

Enkhmaa Luvsannyam ${ }^{1}$, Dhara Patel ${ }^{1}$, Zaira Hassan ${ }^{1}$, Swetha Nukala ${ }^{1}$, Manoj R. Somagutta ${ }^{1}$, Pousette Hamid $^{2}$

1. Department of Research, California Institute of Behavioral Neurosciences \& Psychology, Fairfield, USA 2. Neurology, California Institute of Behavioral Neurosciences \& Psychology, Fairfield, USA

Corresponding author: Enkhmaa Luvsannyam, luvsenkh@isu.edu

\begin{abstract}
Capsular contracture is one of the most common complications of implant-based breast reconstruction or augmentation surgery. Despite advanced molecular biology, the exact mechanism of this complication is not fully understood. PubMed was searched for studies, published from 2015 to 2020 , focused on potential risk factors and preventions of capsular contracture (CC) in patients who underwent implant-based breast surgery. A total of 533 articles were identified from PubMed, and 13 articles were selected ultimately for our review after eligibility screening and quality appraisal. Common risk factors of CC include biofilm, surgical site infections (SSI), history of prior CC or fibrosis, history of radiation therapy, and implant characteristics. Interventions that decrease the rate of $\mathrm{CC}$ include antibiotic prophylaxis or irrigation, acellular dermal matrix (ADM), leukotriene (LTE) inhibitors, surgical techniques, and others. Multiple risk factors are proposed to be a component of the pathophysiology of CC. However, there is inconsistent evidence supporting these risk factors, and the current data was based on broad heterogeneous studies. While efforts are being undertaken to solve this complication with improved technologies and surgical practices, CC remains to be unsolved. Our objective was to provide a summary of the current data of contributing risk factors as well as preventative and treatment measures for CC.
\end{abstract}

Received 07/17/2020

Review began $07 / 26 / 2020$ Review ended 09/07/2020 Published 09/09/2020

() Copyright 2020

Luvsannyam et al. This is an open access article distributed under the terms of the Creative Commons Attribution License CC-BY 4.0., which permits unrestricted use, distribution, and reproduction in any medium, provided the original author and source are credited.
Categories: Plastic Surgery, General Surgery

Keywords: capsular contracture, breast implant, breast reconstruction

\section{Introduction And Background}

Breast cancer is the most frequently diagnosed cancer in women around the world, and up to $41 \%$ of patients who undergo mastectomy receive breast reconstruction [1]. Breast implant has been present since the 1960s, and $65 \%$ of reconstruction surgery is implant-based in the United States [2]. The main goals of breast reconstruction are to reshape the breast due to tissue loss following breast cancer; to revise and fix the previous reconstruction surgery; and to augment the breast for cosmetic purposes. Along with its advantages for physical and psychological satisfaction given for the patients, complication rates are high following implant-based breast reconstruction especially for capsular contracture (CC).

$\mathrm{CC}$ is a distressing complication of breast implant surgery and often requires revision operation. Up to half of the patients develop CC, and 30\% of them suffer from CC with Baker rates III and IV following implantbased breast reconstruction [3,4]. Risk factors found to be associated with CC include previous capsular fibrosis, radiation therapy, contamination with biofilm-producing bacteria, surgical site infections (SSI), and immune response to the foreign material $[3,5]$. The expression of toll-like receptor 4 is also seen in periimplant tissue fibrosis and may play a role in myofibroblast differentiation to induce CC development [6]. The exact mechanism of the pathophysiology of CC formation is still unknown. An infection has been linked with the formation of CC extensively. Generally, breast surgery is considered to be a clean surgery but the postoperative SSI rate rises by $2 \%-2.9 \%$ in augmentation and is the most common cause of readmission $[7,8]$. The common organisms identified are Staphylococcus epidermidis and S. aureus, Escherichia, Pseudomonas, Propionibacterium, and Corynebacterium $[9,10]$.

While the procedures for breast surgery and pre- or postoperative interventions are being improved, the causes and prevention methods for CC remain unclear. This study aims to review the risk factors associated with CC and to outline the available preventative and treatment measures to reduce the rate of CC.

\section{Review}

\section{Methods}

Protocol 
The protocol of this systematic review follows the Preferred Reporting Items for Systematic Reviews and Meta-Analyses Protocol (PRISMA-P) 2009 guideline.

Search Strategy, Study Selection, and Data Extraction

Electronic databases PubMed Central (PMC) and Medical Subject Heading (MeSH) were searched for articles. The keywords included in the search strategy include: "Implant Capsular Contracture/microbiology" OR "Implant Capsular Contracture/prevention and control" OR "Implant Capsular Contracture/statistics and numerical data"; "Mastectomy/complications" OR "Mastectomy/mortality" OR "Mastectomy/psychology"; AND "Surgical Wound Infection/analysis" OR "Surgical Wound Infection/microbiology" OR "Surgical Wound Infection/mortality" OR "Surgical Wound Infection/prevention and control" OR "Surgical Wound Infection/statistics and numerical data". No language restrictions were applied.

Three authors screened the titles and abstracts using the inclusion and exclusion criteria to identify the eligibility of the studies. Reference duplicates were manually checked by one author. The inclusion criteria were studies within the last five years (2015-2020) and studies with only human subjects that focused on CC and SSIs following breast surgery. We included various types of studies except for letters to the editors, animal and in vitro studies. Two authors extracted the following data from each study independently: study title, publication date, study design, sample size, mean follow-up, and mean age of the patients.

We identified 533 publications total from PubMed PMC and MeSH search and excluded 520 publications due to duplication, ineligibility, incomplete data, and irrelevance to our topic. Thirteen studies were ultimately selected and included in our review. Preferred Reporting Items for Systematic Reviews and Meta-Analyses (PRISMA) flowchart diagram of literature retrieval is shown in Figure 1.

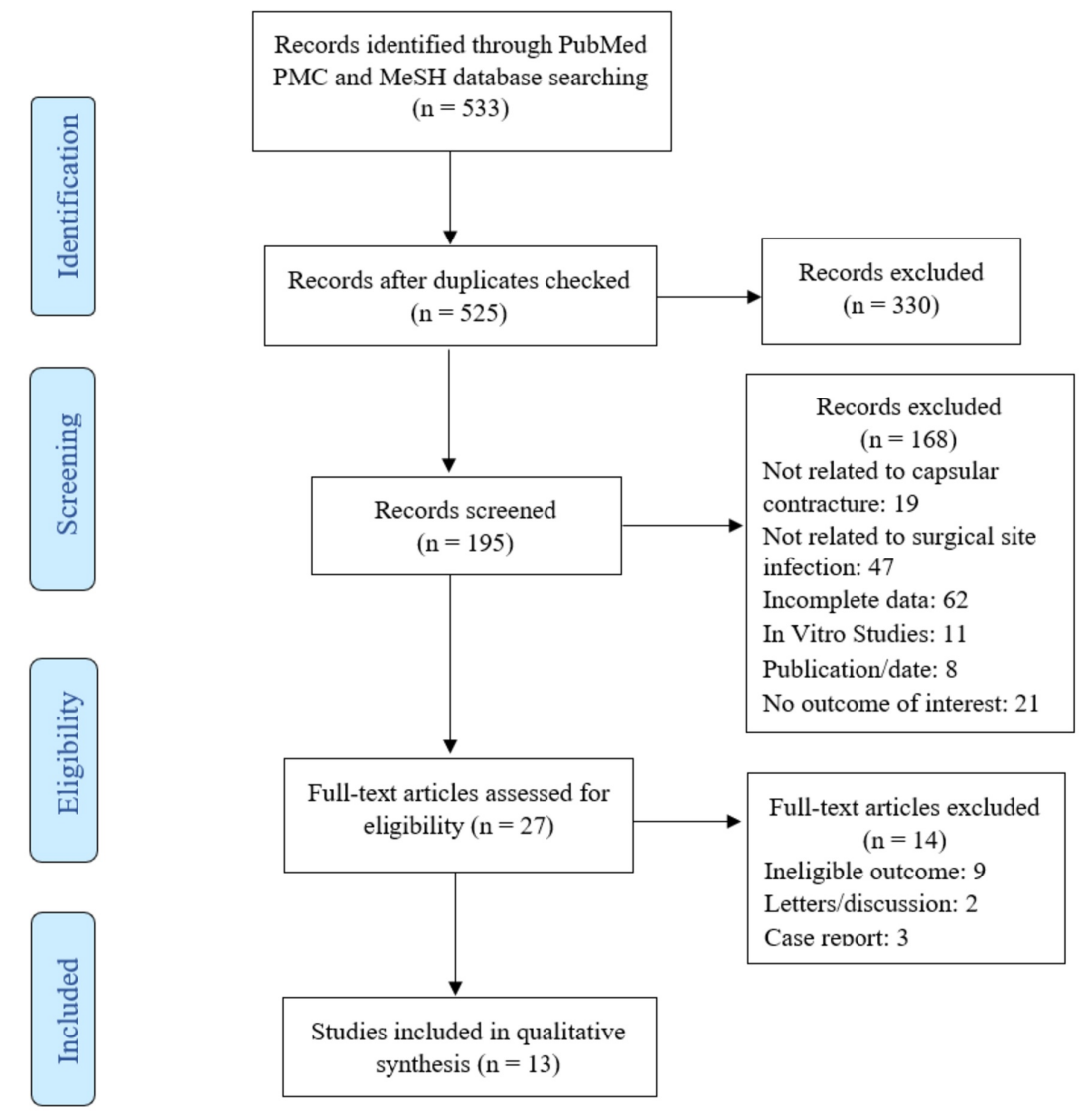

FIGURE 1: The PRISMA diagram showing identification, screening, and eligibility of the literature retrieved

Quality of the Studies and Risk of Bias Within Studies

Four authors assessed the quality of included studies and risk of bias using the Newcastle-Ottawa Scale (NOS) for observational studies; A Measurement Tool to Assess Systematic Reviews (AMSTAR 2) for systematic reviews and meta-analysis; and Cochrane risk of bias tool for randomized controlled trials 


\section{Cureus}

(RCTs).

\section{Results}

Study Characteristics

The 13 selected articles include two RCTs, one controlled trial (CT) without randomization, two cohort studies, one systematic review, one meta-analysis, one cross-sectional study, three retrospective studies, and two traditional reviews. Patients in the included studies are women who underwent either mastectomy followed by implant-based reconstruction surgery or implant-based breast augmentation only. The study characteristics are summarized in Table 1.

\begin{tabular}{|c|c|c|c|c|c|}
\hline $\begin{array}{l}\text { Authors, Year } \\
\text { [References] }\end{array}$ & Study Design & Location & $\begin{array}{l}\text { Sample } \\
\text { Size }\end{array}$ & Mean Follow-Up (months) & Mean Patient Age \pm SD (years) \\
\hline Tanner, 2018 [4] & $\begin{array}{l}\text { Retrospective } \\
\text { analysis }\end{array}$ & England & 214 & 20.2 & $40 \pm 12.6$ \\
\hline $\begin{array}{l}\text { Ajdic et al., } 2016 \\
{[5]}\end{array}$ & Traditional review & $\begin{array}{l}\text { United } \\
\text { States }\end{array}$ & N/A & N/A & N/A \\
\hline $\begin{array}{l}\text { Palubicka et al., } \\
2019 \text { [9] }\end{array}$ & $\begin{array}{l}\text { Retrospective } \\
\text { analysis }\end{array}$ & Poland & 2129 & N/A & $55 \pm 13.1$ (range: $34.1-74.6$ ) \\
\hline $\begin{array}{l}\text { Sinha et al., } \\
2017 \text { [11] }\end{array}$ & $\begin{array}{l}\text { Prospective cohort } \\
\text { study }\end{array}$ & $\begin{array}{l}\text { United } \\
\text { States }\end{array}$ & 1024 & 12 & $48.4 \pm 10.6$ \\
\hline $\begin{array}{l}\text { Samargandi et } \\
\text { al., } 2018[22]\end{array}$ & Systematic review & $\begin{array}{l}\text { United } \\
\text { States }\end{array}$ & N/A & N/A & $\begin{array}{l}34.3 \text { ( } 5 \text { studies) Not specified ( } 2 \\
\text { studies) }\end{array}$ \\
\hline $\begin{array}{l}\text { Viola et al., } 2019 \\
\text { [23] }\end{array}$ & $\begin{array}{l}\text { Randomized } \\
\text { controlled trial }\end{array}$ & $\begin{array}{l}\text { United } \\
\text { States }\end{array}$ & 241 & 6 & $\begin{array}{l}53 \text { (range: } 32-76 \text {, infected patients) } 47 \\
\text { (range: } 22-81 \text {, uninfected patients) }\end{array}$ \\
\hline $\begin{array}{l}\text { Sobti et al., } \\
2020 \text { [29] }\end{array}$ & Cohort study & $\begin{array}{l}\text { United } \\
\text { States }\end{array}$ & 47 & $\begin{array}{l}25.3 \pm 10.8 \text { (prepectoral } \\
\text { group) } 27.0 \pm 11.3 \\
\text { (subpectoral) }\end{array}$ & $50.8 \pm 11.3$ \\
\hline $\begin{array}{l}\text { Bresnick, } 2017 \\
{[38]}\end{array}$ & $\begin{array}{l}\text { Nonrandomized } \\
\text { controlled trial }\end{array}$ & $\begin{array}{l}\text { United } \\
\text { States }\end{array}$ & 1122 & 6 & Range: $22-60$ \\
\hline $\begin{array}{l}\text { Poppler et al., } \\
2015 \text { [40] }\end{array}$ & $\begin{array}{l}\text { Retrospective } \\
\text { cross-sectional } \\
\text { study }\end{array}$ & $\begin{array}{l}\text { United } \\
\text { States }\end{array}$ & 26 & N/A & $49.6 \pm 5.5$ (range: $40-64)$ \\
\hline $\begin{array}{l}\text { Hai et al., } 2020 \\
\text { [41] }\end{array}$ & Meta-analysis & $\begin{array}{l}\text { United } \\
\text { States }\end{array}$ & N/A & N/A & N/A \\
\hline $\begin{array}{l}\text { Straub et al., } \\
2015 \text { [42] }\end{array}$ & Traditional review & $\begin{array}{l}\text { United } \\
\text { States }\end{array}$ & N/A & N/A & N/A \\
\hline $\begin{array}{l}\text { McCarthy et al., } \\
2012 \text { [43] }\end{array}$ & $\begin{array}{l}\text { Randomized } \\
\text { controlled trial }\end{array}$ & $\begin{array}{l}\text { United } \\
\text { States }\end{array}$ & 70 & 12 & 51 (range: 29-72) \\
\hline $\begin{array}{l}\text { Papadopoulos } \\
\text { et al., } 2018\end{array}$ & $\begin{array}{l}\text { Retrospective } \\
\text { study }\end{array}$ & Germany & 15 & 11.9 (range: $3-30$ ) & 49.2 (range: 22-72) \\
\hline
\end{tabular}

TABLE 1: Characteristics of the Included Studies $(n=13)$

Overall Results and Recommendations of the Studies

Multiple risk factors are mentioned to be associated with CC across studies. The number of studies discussed each topic include 14 studies about infection with biofilm-producing bacteria and SSIs; six studies about radiation therapy and previous fibrosis; nine studies about antibiotics and irrigations; six studies about implant surface, size, and placement; three studies about acellular dermal matrix (ADM); three studies about leukotriene antagonists (LTE); one study about toll-like receptor 4; and one study about Thy1(CD90) expression. The suggested risk factors and preventions for CC are summarized in Table 2 . 


\section{Cureus}

\begin{tabular}{|c|c|c|c|}
\hline $\begin{array}{l}\text { Risk } \\
\text { Factors }\end{array}$ & Prevention & Treatment & Additional Comment/Recommendation \\
\hline $\begin{array}{l}\text { Implant } \\
\text { surface }\end{array}$ & $\begin{array}{l}\text { Textured implants instead of } \\
\text { smooth implants; antibiotics } \\
\text { for biofilm-producing bacteria. }\end{array}$ & $\begin{array}{l}\text { Capsulectomy for } \\
\text { definitive treatment; } \\
\text { open capsulotomy }\end{array}$ & $\begin{array}{l}\text { Microtextured implants show lower rates of CC compared to } \\
\text { macrotextured implants. Textured implants may contribute to } \\
\text { a higher risk of biofilm productions compared to the smooth } \\
\text { implant. Future study indication: association between } \\
\text { textured implants, biofilm, and ALCL. }\end{array}$ \\
\hline $\begin{array}{l}\text { Toll-like } \\
\text { receptor } 4\end{array}$ & $\begin{array}{l}\text { Targeting toll-like receptor } 4 \\
\text { expressed by fibroblasts and } \\
\text { myofibroblasts }\end{array}$ & $\begin{array}{l}\text { Reducing the } \\
\text { expression of TLR } 4 \\
\text { and its correlation } \\
\text { with estrogen } \\
\text { receptor- } \beta\end{array}$ & $\begin{array}{l}\text { Future indication: more evidence-based trials in the } \\
\text { association between TLR } 4 \text { and capsular fibrosis, as well as } \\
\text { its correlation with estrogen receptor- } \beta \text { expression. }\end{array}$ \\
\hline Biofilm SSI & $\begin{array}{l}\text { Preoperative antiseptic skin } \\
\text { agents; Antibiotic and saline } \\
\text { pocket irrigation; antibiotic } \\
\text { mesh; nipple shield } \\
\text { (prevention from endogenous } \\
\text { breast flora); surgical } \\
\text { techniques }\end{array}$ & $\begin{array}{l}\text { IV antibiotics; } \\
\text { capsulectomy for } \\
\text { definitive treatment }\end{array}$ & $\begin{array}{l}\text { Lower rate of biofilm-related CC seen in CHG as preoperative } \\
\text { antiseptic, inframammary incision approach, and subpectoral } \\
\text { implant placement. There is no difference between a triple } \\
\text { antibiotic and saline irrigation in the incidence of biofilm- } \\
\text { related CC. }\end{array}$ \\
\hline $\begin{array}{l}\text { Radiation } \\
\text { therapy }\end{array}$ & $\begin{array}{l}\text { Radiation dose adjustment; } \\
\text { limitations of tissue volume } \\
\text { and duration of therapy }\end{array}$ & $\begin{array}{l}\text { Primarily symptomatic } \\
\text { treatment; inhibition of } \\
\text { TGF- } \beta \text { and associated } \\
\text { signaling molecules; } \\
\text { capsulectomy or open }\end{array}$ & $\begin{array}{l}\text { Radiation increases postoperative complication rates } \\
\text { regardless of timing. Prepectoral breast reconstruction has a } \\
\text { lower rate of CC in an irradiated patient vs. subpectoral } \\
\text { breast reconstruction. Future study indication: molecular } \\
\text { mechanisms of fibrosis to reduce the inflammatory responses } \\
\text { and control myofibroblast development. }\end{array}$ \\
\hline $\begin{array}{l}\text { Previous } \\
\text { fibrosis }\end{array}$ & & capsurotomy & $\begin{array}{l}\text { Previous fibrosis formation significantly increases the risk of } \\
\text { future } \mathrm{CC} \text { development. }\end{array}$ \\
\hline $\begin{array}{l}\text { Thy1(CD90) } \\
\text { expression }\end{array}$ & $\begin{array}{l}\text { Targeting Thy1 expression in } \\
\text { fibroblasts; salinomycin } \\
\text { (decreased Thy1 expression) }\end{array}$ & $\begin{array}{l}\text { Reduction of Thy } 1 \\
\text { expression to prevent } \\
\text { further development } \\
\text { of fibrosis }\end{array}$ & $\begin{array}{l}\text { Depletion of Thy } 1 \text { prevented myofibroblast formation } \\
\text { in capsular fibroblasts and significantly decreased a-smooth } \\
\text { muscle actin and collagen levels. Future study indication: } \\
\text { anti-scarring ability of salinomycin in radiation-induced CC. }\end{array}$ \\
\hline
\end{tabular}

\section{TABLE 2: Summary of the Risk Factors Associated With Breast Implant Capsular Contracture}

ALCL, anaplastic large-cell lymphoma; TLR, toll-like receptor; TGF, transforming growth factor; SSI, surgical site infection; CHG, chlorhexidine gluconate; CC, capsular contracture.

SSI is a major postoperative complication that can cause CC formation. The risk of SSI is higher with reconstruction performed during the primary surgery, and the incidence rate of acute infection is higher than that of late infections $[7,8,9]$. A recent study states that SSIs are underestimated in implant-based breast reconstructions because the majority of them occur later than 30 days following surgery, causing persistent inflammation and subsequent formation of late-onset CC [11]. Implant removal after breast reconstruction surgery has shown to be associated with hypertension, elevated BMI $>25$, and diabetes, but the infection is the most common cause of implant loss [12-15]. Post breast implant surgery morbidity has an association with operation time. Longer operation time has significantly increased the length of hospital stay due to complications such as infection [16]. Moreover, postoperative drains aid in the prevention of seroma and bacterial infection; however, prolonged drain use has significantly increased the rate of SSI, and early drain removal is encouraged as early as postoperative day seven [17,18].

\section{Antibiotics and Irrigations}

Preoperative skin antiseptic agents are known to reduce postoperative complications. CC rate is reduced with povidone-iodine and antimicrobial irrigations [19]; however, chlorhexidine gluconate was found to be more effective than povidone-iodine for reduction of biofilm-related CC [20]. A study has found that there is no difference between triple antibiotic vs. saline irrigation in the reduction of CC incidence [21]. The available evidence suggesting antimicrobial irrigation in the reduction of CC is weak and inconclusive [22]. 
Staphylococci species are the most common axillary flora, and antibiotics targeted at these species do not show a significant impact on SSIs [23]. Preoperative prophylaxis has not significantly reduced SSIs in breast cancer surgery [24], and prolonged postoperative antibiotic prophylaxis also has not shown to decrease implant loss or highly virulent infections [25]. Patient compliance plays an important role in preventing SSIs, and medication noncompliance doubles the risk of infection in breast surgery [26]. In primary breast augmentation, most organisms in acute infections are Gram-positives and are adequately covered by a single dose of IV cephalosporin; clindamycin or vancomycin is recommended in individuals with $\beta$-lactam allergies [8]. The antibiotic is broadened with fluoroquinolones or vancomycin in late infections or secondary surgeries due to mixed organisms with both Gram-positives and Gram-negatives [8].

Radiation Therapy and Implant Surface

Post-mastectomy radiation therapy leads to higher rates of CC [27]. Several studies report that patients who had radiation therapy are more likely to experience reconstruction failure due to complications. The expression of Thy1 (CD90), which has an important role in scar tissue formation, is shown to be increased by radiation; thus, targeting the Thy1 receptor may decrease the rate of radiation-induced fibroproliferation of capsular tissue [28]. Muscle fibrosis is another possible contributor to CC in irradiated patients with subpectoral implant placement vs. prepectoral implant placement [29].

Breast implant characteristics especially implant surface seem to play a role in CC. Studies have analyzed that smooth implants, compared to textured implants, are significantly associated with CC, and the choice of the textured implant may reduce the risk of CC $[4,30]$. Moreover, microtextured implants may have lower rates of CC compared to macrotextured implants [4]. However, macrotextured implants have been associated with increased risk of anaplastic large-cell lymphoma (ALCL) significantly compared to smooth or microtextured implants [31,32]. Breast implant-associated ALCL is a rare complication and may have an infectious cause as seen by the bacterial biofilm on the implant [33].

\section{ADM and Leukotriene (LTE) Antagonists}

Long-term study has shown that the incidence of CC remains low in patients who had implant-based breast reconstruction with $\mathrm{ADM}$ with or without radiation therapy and states that it may truly prevent early-onset CC [34]. Due to the early formation of peri-implant fibrosis, ADM may play an important role in preventing the CC formation rather than delaying the formation [34]. In terms of the difference between the matrices, fenestrated acellular matrices are not significantly different than nonfenestrated matrices in the reduction of CC rates [35]; however, meshed acellular matrices significantly decrease the rates of minor complications including postoperative drain duration, narcotic use, and length of stay vs. unmeshed matrices [36].

LTE antagonists have been known to prevent and treat CC. Multiple studies have found that the patients who used LTE antagonists, either montelukast or zafirlukast, have significantly decreased rate of CC compared to the control group [37-39]. Although there is a short-term benefit in CC reduction rates with the use of LTE antagonists, its long-term side effects such as liver damage are not known in depth [38].

\section{Discussion}

CC remains the most frequently recorded complication and cause of reoperation following breast implant surgery; yet, the pathophysiology of CC has not been clearly defined, and the prevention remains to be unresolved [30]. Multiple literature reviews analyzed the risk factors associated with CC and preventative measures, and the findings are inconclusive and lack evidence. The purpose of this systematic review was to analyze the risk factors, etiology, and preventions for CC and to provide recommendations according to the current literature.

\section{Risk Factors of CC}

Microbial biofilm is challenging to treat and can cause chronic inflammation and the formation of capsular fibrosis $[3,5]$. While most studies support that infection with biofilm-producing bacteria leads to the development of CC, few studies found no correlation among biofilm and CC. A study suggests that confirming the presence of biofilm is difficult and requires direct visualization of the colony [40]. Moreover, bacteria may form biofilm for its self-defense from unfavorable surroundings, and biofilm may not be the cause of CC, instead, it is the environmental trigger causing both biofilm and fibrosis independently [40].

SSIs are a common cause of breast reconstruction failure following breast surgery [17]. The association between SSI and CC is unclear and lacks evidence. Patients undergoing a mastectomy followed by immediate implant-based reconstruction surgery have twice the rate of SSI than patients without immediate reconstruction surgery [7]. The appropriate antibiotics are recommended less than 60 minutes before the incision to be more effective [8]. Although antibiotics are widely used to prevent SSI, the antimicrobial prophylaxis in breast surgery is controversial. Studies have found that pre- and postoperative antibiotics did not significantly decrease the rate of SSIs [23]; and peri-operative prophylaxis also has no impact in preventing SSI in breast cancer surgery [24]. Extensive use of antibiotics increases the risk of antibiotic 
resistance and disrupts the normal gastrointestinal flora resulting in Clostridium difficile-related pseudomembranous colitis [41]. There is not enough evidence supporting that antibiotic irrigation of the implant pocket plays a role in CC prevention [22].

Implant surface may or may not affect biofilm formation. The textured implants may cause higher rates of biofilm formation compared to smooth implants, but a study also found no difference between textured and smooth implants in biofilm formation [5]. A recent study suggests that microtextured implants contribute to a low rate of CC formation; however, this study did not have a control group, and a randomized study with different types of implant textures would be useful in understanding the association between implant surface and formation of CC [4]. Deeper research is also warranted to prove the relationship between macrotextured implants and ALCL due to a lack of evidence.

All the studies support that post-mastectomy radiation therapy is a strong risk factor for postoperative complications including CC and SSIs [9,29,34]. The formation of radiation-induced fibrosis is mainly affected by the radiation dose, the volume of tissue, and the duration of the therapy [42]. Patients with systemic lupus erythematosus, systemic scleroderma, Marfan syndrome, and specific genetic mutations are more prone to radiation-induced fibrosis [42]. Although there is no proven intervention to prevent radiationinduced CC, reduction of inflammation and matrix synthesis has a crucial role in the aims of therapeutic development. More specifically, targeting TGF- $\beta$ and its associated signaling molecules is important in the management approach [42].

Management Approaches to CC

$\mathrm{ADM}$ is a popular intervention to reduce the rate of CC. An RCT has found that ADM does not reduce postoperative pain [43], but another study states that meshed ADM has significantly reduced overall complications including postoperative pain [36]. Multiple studies mention the promising outcomes of ADM in the incidence of CC; however, most of these studies were short of duration. Therefore, independent, longterm studies with controlled groups are indicated for use of ADM in the prevention of CC.

LTE antagonists are used by many plastic surgeons to some extent for the treatment of CC, but there is no clear evidence of the benefit of these medications currently. The available information on how LTE antagonists work on the pathogenesis of CC is limited. Several studies have shown favorable outcomes with LTE antagonists in decreasing the incidence of CC and support the use of these medications in a safe way [37-39]. However, these studies lack evidence on the prevalence and side effects of long-term use, highlighting the need for future studies to determine the clinical efficacy and safety as well as to develop a clear standard treatment protocol.

A recent study demonstrated fat grafting in women with the previous CC to restore the soft tissue thickness and found that it significantly reduces pain and tension due to CC [44]. The study suggests that lipofilling can reduce CC grade and reduce fibrotic damage, especially after radiation-induced CC [44]. Although the study showed a promising effect of lipofilling in CC treatment, the study had a small sample size and high risk of bias; therefore, further studies with larger sample size and control groups are warranted.

Currently, the gold standard treatment of CC is capsulectomy to remove the capsule and replace it with a new implant. Surgeons performed open capsulotomy, which does not remove the capsule from the body and reinserts the intact implant, more often in the past. A retrospective study suggests that an open capsulotomy is a safe treatment and there is no significant difference between capsulectomy and open capsulotomy in the CC recurrence rate [45]. However, this study consists of small sample size and does not provide adequate evidence. Open capsulotomy would also be not useful if the underlying etiology of CC is an infection.

Limitations

There are several limitations to our study. First, the studies included in this review were obtained from a single database and were mixed studies with heterogeneity in terms of sample size, follow-up duration, control groups, and randomization, which may create bias in reporting the development and different stages of CC. Second, we selected studies from 2015 to 2020, except one study in 2012 [45], to have the most current data; however, this may cause missing of the valuable information from previous studies. We were not able to obtain all the full articles relevant to our topic; thus information taken was limited to abstracts only. Third, only two studies were RCTs, and one study was CT without randomization; therefore, more RCTs are needed for stronger evidence.

\section{Future Directions}

Given the limited number of studies with evidence-based medicine on this topic, well-designed studies are indicated in the future. According to the current literature, the incidence of SSI and CC has decreased with antibiotic prophylaxis, textured implant, ADM, leukotriene antagonists, and an open capsulotomy; however, these interventions have not been proved. The important question to be addressed should be more focused on the pathogenesis of CC, which has been debatable. What exactly is the cause of CC? Is it multifactorial? 
What is the biggest factor contributing to the pathogenesis of CC among other factors? Focusing on these questions will help further studies to search for strategies about particular preventions and treatment approaches for CC.

\section{Conclusions}

CC is most likely to be multifactorial, and the exact mechanism of pathogenesis of CC formation is unknown. The available evidence on risk factors associated with CC is weak and inconclusive. Our review suggests that infectious cause may be the strongest risk factor of CC etiology, and further studies on this aspect are required. The current literature data on prevention and treatment of CC is heterogeneous, and results are controversial. Greater efforts in developing modern imaging and technologies will continue to provide advanced tools to understand the pathophysiology of CC in depth and further develop preventative and treatment interventions.

\section{Additional Information \\ Disclosures}

Conflicts of interest: In compliance with the ICMJE uniform disclosure form, all authors declare the following: Payment/services info: All authors have declared that no financial support was received from any organization for the submitted work. Financial relationships: All authors have declared that they have no financial relationships at present or within the previous three years with any organizations that might have an interest in the submitted work. Other relationships: All authors have declared that there are no other relationships or activities that could appear to have influenced the submitted work.

\section{References}

1. Panchal H, Matros E: Current trends in post-mastectomy breast reconstruction. Plast Reconstr Surg. 2017, 140:7-13. 10.1097/PRS.0000000000003941

2. Bertozzi N, Pesce M, Santi P, Raposio E: One-stage immediate breast reconstruction: a concise review . Biomed Res Int. 2017, 2017:1-12. 10.1155/2017/6486859

3. Galdiero M, Larocca F, Iovene MR, et al.: Microbial evaluation in capsular contracture of breast implants . Plast Reconstr Surg. 2018, 141:23-30. 10.1097/PRS.0000000000003915

4. Tanner B: Low rate of capsular contracture in a series of 214 consecutive primary and revision breast augmentations using microtextured implants. JPRAS Open. 2018, 15:66-73. 10.1016/j.jpra.2017.10.007

5. Ajdic D, Zoghbi Y, Gerth D, Panthaki ZJ, Thaller S: The relationship of bacterial biofilms and capsular contracture in breast implants. Aesthet Surg J. 2016, 36:297-309. 10.1093/asj/sjv177

6. Segreto F, Carotti S, Tosi D, Pendolino AL, Marangi GF, Morini S, Persichetti P: Toll-like receptor 4 expression in human breast implant capsules: localization and correlation with estrogen receptors. Plast Reconstr Surg. 2016, 137:792-798. 10.1097/01.prs.0000479941.42174.f1

7. Olsen MA, Nickel KB, Fox IK, et al.: Incidence of surgical site infection following mastectomy with and without immediate reconstruction using private insurer claims data. Infect Control Hosp Epidemiol. 2015, 36:907-14. 10.1017/ice.2015.108

8. Prantl L, Momeni A, Brebant V, Kuehlmann B, Heine N, Biermann N, Brix E: Recommendations for the use of antibiotics in primary and secondary esthetic breast surgery. Plast Reconstr Surg Glob Open. 2020, 8:2590. 10.1097/GOX.0000000000002590

9. Palubicka A, Jaworski R, Wekwejt M, Swieczko-Zurek B, Pikula M, Jaskiewicz J, Zielinski J: Surgical site infection after breast surgery: a retrospective analysis of 5-year postoperative data from a single center in poland. Medicina (Kaunas). 2019, 55:512. 10.3390/medicina55090512

10. Cohen JB, Carroll C, Tenenbaum MM, Myckatyn TM: Breast implant-associated infections: the role of the national surgical quality improvement program and the local microbiome. Plast Reconstr Surg. 2015, 136:921-9. 10.1097/PRS.0000000000001682

11. Sinha I, Pusic AL, Wilkins EG, et al.: Late surgical site infection in immediate implant-based breast reconstruction. Plast Reconstr Surg. 2017, 139:20-28. 10.1097/PRS.0000000000002839

12. Szymankiewicz M, Nowikiewicz T, Biedka M: Significance of infections in implant loss after breast reconstruction in the course of breast cancer treatment. Pol J Microbiol. 2019, 68:343-351. 10.33073/pjm2019-037

13. Masoomi H, Fairchild B, Marques ES: Frequency and predictors of 30-day surgical site complications in autologous breast reconstruction surgery. World J Plast Surg. 2019, 8:200-207. 10.29252/wjps.8.2.200

14. Garland M, Hsu FC, Clark C, Chiba A, Howard-McNatt M: The impact of obesity on outcomes for patients undergoing mastectomy using the ACS-NSQIP data set. Breast Cancer Res Treat. 2018, 168:723-726. 10.1007/s10549-017-4651-4

15. Rifkin WJ, Kantar RS, Cammarata MJ, et al.: Impact of diabetes on 30-day complications in mastectomy and implant-based breast reconstruction. J Surg Res. 2019, 235:148-159. 10.1016/j.jss.2018.09.063

16. Allan J, Goltsman D, Moradi P, Ascherman JA: The effect of operative time on complication profile and length of hospital stay in autologous and implant-based breast reconstruction patients: An analysis of the 2007-2012 ACS-NSQIP database. J Plast Reconstr Aesthet Surg. 2020, 73:1292-1298. 10.1016/j.bjps.2020.02.003

17. Chen CF, Lin SF, Hung CF, Chou P: Risk of infection is associated more with drain duration than daily drainage volume in prosthesis-based breast reconstruction. A cohort study. Medicine (Baltimore). 2016, 95:5605. 10.1097/MD.0000000000005605

18. Hadad E, Wiser I, Rosenthal A, Landau G, Ziv E, Heller L: Suction drains in esthetic breast implant exchange are associated with surgical site infections: a retrospective cohort study. J Plast Reconstr Aesthet Surg. 2017, 
70:1635-1640. 10.1016/j.bjps.2017.06.034

19. Yalanis GC, Liu EW, Cheng HT: Efficacy and safety of povidone-iodine irrigation in reducing the risk of capsular contracture in aesthetic breast augmentation. A systematic review and meta-analysis. Plast Reconstr Surg. 2015, 136:687-698. 10.1097/PRS.0000000000001576

20. Carvajal J, Carvajal M, Hernández G: Back to basics: could the preoperative skin antiseptic agent help prevent biofilm-related capsular contracture?. Aesthet Surg J. 2019, 12:848-859. 10.1093/asj/sjy216

21. Drinane JJ, Kortes MJ, Bergman RS, Folkers BL: Evaluation of antibiotic irrigation versus saline irrigation in reducing the long-term incidence and severity of capsular contraction after primary augmentation mammoplasty. Ann Plast Surg. 2016, 77:32-6. 10.1097/SAP.0000000000000302

22. Samargandi OA, Joukhadar N, Al Youha S, Thoma A, Williams J: Antibiotic irrigation of pocket for implantbased breast augmentation to prevent capsular contracture: a systematic review. Plast Surg (Oakv). 2018, 26:110-119. 10.1177/2292550317747854

23. Viola GM, Rolston KV, Butler C, et al.: Evaluation of current perioperative antimicrobial regimens for the prevention of surgical site infections in breast implant-based reconstructive surgeries. Plast Reconstr Surg Glob Open. 2019, 7:2342. 10.1097/GOX.0000000000002342

24. Zhang H, Wang Y, Yang S, Zhang Y: Peri-operative antibiotic prophylaxis does not reduce surgical site infection in breast cancer. Surg Infect (Larchmt). 2020, 21:268-274. 10.1089/sur.2019.116

25. Monroig K, Ghosh K, Marquez JE, et al.: Do postoperative prophylactic antibiotics reduce highly virulent infections?: an analysis of 660 tissue expander breast reconstructions. Ann Plast Surg. 2020, 85:S50-S53. 10.1097/SAP.0000000000002325

26. Gil Conesa M, Climent Martínez NM, Del Moral Luque JA, Durán Poveda M, Rodríguez Villar D, Rodríguez Caravaca G: Evaluation of compliance with the antibiotic prophylaxis protocol in breast surgery and its effect on the incidence of surgical infection. An Sist Sanit Navar. 2019, 23:139-146. 10.23938/ASSN.0637

27. Olinger TA, Berlin NL, Qi J, et al.: Outcomes of immediate implant-based mastectomy reconstruction in women with previous breast radiation. Plast Reconstr Surg. 2020, 145:1029e-1036e. 10.1097/PRS.0000000000006811

28. Hansen TC, Woeller CF, Lacy SH, Koltz PF, Langstein HN, Phipps RP: Thy1 (CD90) expression is elevated in radiation-induced periprosthetic capsular contracture: implication for novel therapeutics. Plast Reconstr Surg. 2017, 140:316-326. 10.1097/PRS.0000000000003542

29. Sobti N, Weitzman RE, Nealon KP, et al.: Evaluation of capsular contracture following immediate prepectoral versus subpectoral direct-to-implant breast reconstruction. Sci Rep. 2020, 10:1137. 10.1038/s41598-020-58094-4

30. Calobrace MB, Stevens WG, Capizzi PJ, Cohen R, Godinez T, Beckstrand M: Risk factor analysis for capsular contracture: a 10-year sientra study using round, smooth, and textured implants for breast augmentation. Plast Reconstr Surg. 2018, 141:20-28. 10.1097/PRS.0000000000004351

31. Adams WP Jr, Culbertson EJ, Deva AK, et al.: Macrotextured breast implants with defined steps to minimize bacterial contamination around the device: experience in 42,000 implants. Plast Reconstr Surg. 2017, 427:431. 10.1097/PRS.0000000000003575

32. Loch-Wilkinson A, Beath KJ, Knight RJW, et al.: Breast implant-associated anaplastic large cell lymphoma in Australia and New Zealand: high-surface-area textured implants are associated with increased risk. Plast Reconstr Surg. 2017, 140:645-654. 10.1097/PRS.0000000000003654

33. Hu H, Johani K, Almatroudi A, et al.: Bacterial biofilm infection detected in breast implant-associated anaplastic large-cell lymphoma. Plast Reconstr Surg. 2016, 137:1659-69. 10.1097/PRS.0000000000002010

34. Salzberg CA, Ashikari AY, Berry C, Hunsicker LM: Acellular dermal matrix-assisted direct-to-implant breast reconstruction and capsular contracture: a 13-year experience. Plast Reconstr Surg. 2016, 138:329-337. 10.1097/PRS.0000000000002331

35. Mowlds DS, Salibian AA, Scholz T, Paydar KZ, Wirth GA: Capsular contracture in implant-based breast reconstruction: examining the role of acellular dermal matrix fenestrations. Plast Reconstr Surg. 2015, 136:629-635. 10.1097/PRS.0000000000001570

36. Hagarty SE, Yen LL, Luo J, Fosco CR, Gomez K, Khare M: Decreased length of postoperative drain use, parenteral opioids, length of stay, and complication rates in patients receiving meshed versus unmeshed acellular dermal matrix in 194 submuscular tissue expander-based breast reconstructions: a single-surgeon cohort study. Plast Reconstr Surg. 2020, 145:889-897. 10.1097/PRS.0000000000006635

37. Wang Y, Tian J, Liu J: Suppressive effect of leukotriene antagonists on capsular contracture in patients who underwent breast surgery with prosthesis: a meta-analysis. Plast Reconstr Surg. 2020, 145:901-911. 10.1097/PRS.0000000000006629

38. Bresnick SD: Prophylactic leukotriene inhibitor therapy for the reduction of capsular contracture in primary silicone breast augmentation: experience with over 1100 cases. Plast Reconstr Surg. 2017, 139:379-385. 10.1097/PRS.0000000000003006

39. Graf R, Ascenço AF, Freitas Rda S, et al.: Prevention of capsular contracture using leukotriene antagonists . Plast Reconstr Surg. 2015, 136:592-596. 10.1097/PRS.0000000000001683

40. Poppler L, Cohen J, Dolen UC, et al.: Histologic, molecular, and clinical evaluation of explanted breast prostheses, capsules, and acellular dermal matrices for bacteria. Aesthet Surg J. 2015, 35:653-668. 10.1093/asj/sjv017

41. Hai Y, Chong W, Lazar M: Extended prophylactic antibiotics for mastectomy with immediate breast reconstruction: a meta-analysis. Plast Reconstr Surg Glob Open. 2020, 8:2613. 10.1097/GOX.0000000000002613

42. Straub JM, New J, Hamilton CD, Lominska C, Shnayder Y, Thomas SM: Radiation-induced fibrosis: mechanisms and implications for therapy. J Cancer Res Clin Oncol. 2015, 141:1985-1994. 10.1007/s00432015-1974-6

43. McCarthy CM, Lee CN, Halvorson EG, Reidel E, Pusic AL, Mehrara BJ, Disa JJ: The use of acellular dermal matrices in two-stage expander/implant reconstruction: a multi-center, blinded, randomized controlled trial. Plast and Reconstr Surg. 2012, 130:57-66. 10.1097/PRS.0b013e31825f05b4

44. Papadopoulos S, Vidovic G, Neid M, Abdallah A: Using fat grafting to treat breast implant capsular 


\section{Cureus}

contracture. Plast Reconstr Surg Globe Open. 2018, 6:1969. 10.1097/GOX.0000000000001969

45. Swanson E: Open capsulotomy: an effective but overlooked treatment for capsular contracture after breast augmentation. Plast Reconstr Surg Glob Open. 2016, 4:1096. 10.1097/GOX.0000000000001096 